\title{
INDIVIDUAL AND CONTEXTUAL FACTORS AFFECTING DPT IMMUNIZATION IN INDONESIA
}

\author{
Resti Wahyuni $^{1^{*}}$, Titik Harsanti ${ }^{2}$ \\ ${ }^{1}$ Badan Pusat Statistik Provinsi Sulawesi Tengah, Indonesia \\ ${ }^{2}$ Politeknik Statistika STIS, Indonesia \\ *e-mail: resti.wahyuni@bps.go.id
}

\begin{abstract}
Nowadays, diphtheria cases always increase from year to year. Until now, no drug has been found to cure diphtheria, but there is the most effective way of prevention through immunization. It is known that diphtheria sufferers who don't get immunizations increase every year. The purpose of this study is to determine the individual and contextual factors that influence the status of DPT immunization in Indonesia and its trends and to know the diversity between cities. The data used in this study are Susenas KOR and consumption and expenditure (KP) modules. The results of multilevel binary logistic regression analysis indicate that individual factors that influence the status of DPT immunization are residence classification, highest maternal education, ownership of immunization cards, birth order, and household poverty status. While the contextual are the ratio of posyandu to 100,000 population and PDRB. Characteristics of children aged 12-59 who do not get immunizations tend to live in rural areas, have mothers with the highest education in junior high school, don't have immunization cards, who born late in households with many children, and come from poor households. Besides that, there is a diversity of characteristics between cities, which amounted to $22,19 \%$.
\end{abstract}

Keywords: Diphteria, DPT Immunization, Logistic Regression Binary Multilevel

Cite: Wahyuni, R., \& Harsanti, T. (2021). Individual and Contextual Factors Affecting DPT Immunization in Indonesia. Parameter: Journal of Statistics, 2(1), 21-31. distribution, and reproduction in any medium, provided the original work is properly cited. 


\section{INTRODUCTION}

National health development is directed at increasing awareness, willingness, and ability to live a healthy life for everyone so that the highest level of public health can be realized. These national health development goals have been fully summarized in the 2015-2019 National Medium-Term Development Plan (RPJMN). One of the indicators targeted by the 2015-2019 RPJMN in the health sub-sector is the decreasing prevalence of communicable and non-communicable diseases and increasing environmental health. To achieve the government's target, one way is through immunization.

Immunization is a health investment that is considered cheap and effective worldwide because it is proven to be able to prevent and reduce the incidence of illness, disability, and death caused by preventable diseases which are estimated to reach 2 to 3 million deaths every year (Kemenkes RI, 2013). The 2015-2019 RPJMN indicator for the immunization program is the percentage of districts/cities that reach $80 \%$ of complete basic immunizations for infants. Meanwhile, the government's achievement in 2015 was only around 19 provinces $(56 \%)$ in Indonesia had achieved at least $80 \%$ of the target for their babies to get complete basic immunization (Kemenkes RI, 2016).

A child is said to have received complete basic immunization coverage if the baby has received 1 time of hepatitis B immunization at birth, 1 time of BCG immunization, 3 times of DPT-HB immunization, 4 times of polio immunization, and 1 time of measles immunization. 2016). However, the reality is that there are still many toddlers in Indonesia who do not receive complete basic immunization, and there are even toddlers who have never received immunizations at all. Based on the 2017 Indonesian Health Profile published by the Indonesian Ministry of Health, the complete condition of the 2017 basic immunization coverage on a national scale is $90.2 \%$. This figure has not yet reached the 2015-2019 Strategic Plan target which stipulates that the percentage of complete basic immunization on a national scale is $93 \%$.

Incomplete immunization can cause PD3I (Immunization Preventable Diseases), namely diseases that can actually be prevented by vaccines such as measles, polio, diphtheria, pertussis (whooping cough), tetanus, and tuberculosis (Kemenkes RI, 2013). In Indonesia, it is estimated that every year 5\% (1.7 million) deaths in children under five are caused by diseases that can be prevented by immunization (PD3I). PD3I disease that cannot be prevented by immunization can cause outbreaks, including diphtheria.

Today, there is an increase in cases of diphtheria from year to year. The number of cases of diphtheria sufferers in 2015 was 252 cases, increased to 415 in 2016 and then increased again in 2017 to 954 cases. In 2017, diphtheria occurred in 170 regencies/cities and in 30 provinces, with a total of 954 cases, with 44 deaths (Kemenkes RI, 2018).

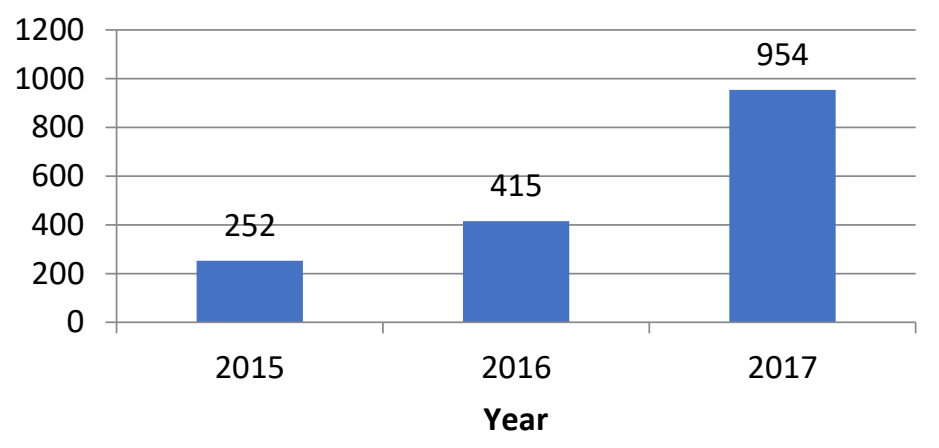

Figure 1. Number of Diphtheria Cases in Indonesia 2015-2017 Source : Profil Kesehatan Indonesia 2015-2017, Kemenkes RI

The increase in diphtheria cases from year to year indicates the failure of the government's immunization program because the increase in diphtheria cases is closely related to the existence of an immunity gap, namely a gap or empty pocket of immunity among residents in an area. This immune vacuum occurs due to the accumulation of groups that are susceptible to diphtheria, because they did not receive immunizations or were not fully immunized (Kemenkes RI, 2017). There is no cure for diphtheria, but there are ways to prevent it. The most effective prevention of diphtheria is through immunization (Kemenkes RI, 2017). Prevention of diphtheria immunization is given through DPT 
immunization which is included in the basic immunization and is given before the baby is 1 year old, namely at the age of 2 months, 3 months, and 4 months. Then continued the provision of DPT immunization which was included in the follow-up immunization given at the age of 18 months (Kemenkes RI, 2017). Completeness of DPT immunization is effective to prevent diphtheria in the future.

Based on the publication of the Indonesian Ministry of Health in the Indonesian Health Profile, diphtheria patients who do not receive DPT immunization continue to increase every year. In 2015, as many as $37 \%$ of diphtheria patients who did not receive immunizations, in 2016 increased to $51 \%$ of all diphtheria patients who did not receive immunizations, increasing again in 2017 as many as 66\% (Kemenkes RI, 2018).

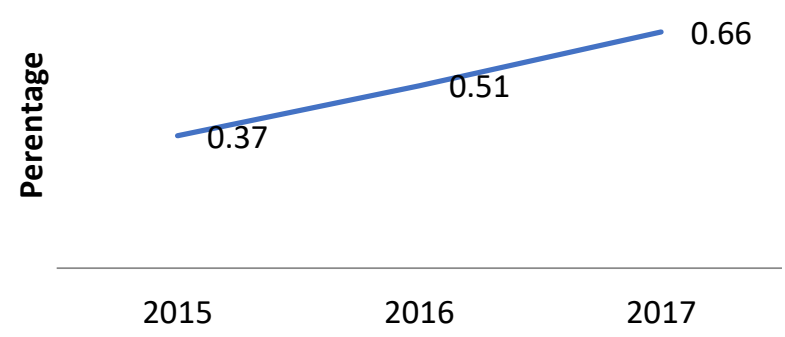

Figure 2. Percentage of Diphtheria Patients Who Didn't Get DPT Immunization Source : Profil Kesehatan Indonesia 2015-2017, Kemenkes RI

From the graph above, it can be seen that more and more people do not receive DPT immunization each year. The alleviation of the unfinished diphtheria epidemic has been the government's concern for a long time but has not yet been resolved. The main cause of this diphtheria outbreak occurred because many people did not get DPT immunization. The continuous increase in the population that does not receive DPT immunization every year indicates that further identification is needed to be able to find solutions to problems in overcoming the increasing percentage of the population who do not receive DPT immunization.

Health problems are very complex problems that are interrelated related to problems other than health itself. Solution to problem public health, not only in terms of their own health, but must be seen from all aspects that have an influence on its problem. Many factors affect the degree of health, both individual factors and public factors. This study has the objectives of, among others, knowing the description of DPT immunization for children aged 12-59 months in Indonesia in 2017, identifying individual and contextual factors in the form of variables from the district/city that affect DPT immunization in Indonesia in 2017, and knowing variations in immunization DPT in Indonesia is caused by differences in characteristics between districts/cities.

\section{MATERIALS AND METHODS}

\section{Literature Review}

Immunization is the process of artificially inducing immunity either by vaccination (active immunization) and by administering antibodies (passive immunization). The purpose of immunization is to prevent the occurrence of certain diseases in a person and eliminate a certain disease in the community (population) or even eliminate a certain disease from the world (Ranuh, 2008). Meanwhile, the general objective of the immunization program is to reduce morbidity, mortality, and disability due to Immunization Preventable Diseases (PD3I) (Kemenkes RI, 2013).

DPT immunization is included in basic and advanced immunization. The DPT vaccine provides protection against three diseases at once, namely diphtheria, pertussis, and tetanus. Diphtheria and tetanus are caused by bacteria so that prevention efforts are only given a modified bacterial toxin so that it is not toxic but can stimulate the formation of antitoxin. While pertussis has other antigens that play a role in the emergence of disease symptoms so that prevention efforts are given in the form of vaccines. Notoatmodjo (2010) says that individual or community health is influenced by two main factors, namely non-behavioral (non-behavioral) factors such as the availability of immunization service facilities and behavioral factors. These behavioral factors have a major influence on the health status of individuals 
and communities. Parents, especially mothers, are very important factors in passing on the health status of their babies. Complete or not basic immunization, especially infant DPT immunization, is very dependent on the behavior of the mother in immunizing her baby (Notoatmodjo, 2010).

\section{Data Source}

This study uses secondary data obtained from the National Social and Economic Survey (Susenas) of KOR and the Consumption and Expenditure (KP) module in 2017 as well as BPS publications, namely all publications of Health Profiles for the thirty-four provinces in Indonesia in 2017. The unit of analysis used in In this study, children aged 12-59 months at the time of enumeration took place. The dependent variable in this study was the DPT immunization status in children aged 12-59 months. The dependent variable was categorized into 2 categories, namely children who received DPT immunization and children who did not receive DPT immunization. While the independent variables used in this study are hierarchical consisting of individual factors and contextual factors. Individual factors include the classification of the area of residence, the mother's highest education, ownership of an immunization card (Maternal and Child Health Book (KIA) or Card to Health (KMS)), birth order, and household poverty status. Meanwhile, contextual factors that become independent variables include GRDP and the ratio of posyandu to 100,000 population.

\section{Analysis Methodology}

Descriptive analysis is used to provide an overview of the response variables and the pattern of the relationship between the explanatory variables and the response variables presented in the form of tables, diagrams, and graphs. The inferential analysis used in this study is binary multilevel logistic regression. The multilevel analysis in this study is a two-level analysis with the first level being the individual (children aged 12-59 months) while the second level is the district/city level for all of Indonesia.

Binary logistic multilevel regression was used because the dependent variable at the lowest level used in this study was data with two categories. In multilevel research, the model formed is divided into two models, namely the null model and the conditional model. Null model is a model that is formed when the independent variables have not been included in the model, both independent variables at level 1 and level 2. This model will be used to estimate intraclass correlation and produce deviance values. Intraclass correlation is the value used to determine the diversity produced by different characteristics between groups. While the deviance value is the value used to determine the best model when a comparison is made between the two models. Conditional model is a model that is formed when independent variables have been entered into the model, both independent variables at level 1 and level 2. So in this condition the model can be called a binary logistic multilevel regression model.

Hox (2010) states that the multilevel regression model can be classified into two basic forms, namely:

1. Multilevel model with random intercept

This model is a model with an intercept as a random effect at level two with the assumption that each group has a different intercept, but has the same slope so that the effect of each explanatory variable on the response variable is the same for each group. The regression model with random intercept is:

For individuals i and group $\mathrm{j}$.

$$
Y_{i j}=\beta_{0 j}+\beta_{1} X_{i j}+e_{i j}
$$

2. Multilevel model with random slope

This model assumes that each group has a different slope but has the same intercept so that it is possible for the influence of the explanatory variable to be different for the response variable for each group. The random slope regression model is:

For individuals i and group $\mathrm{j}$.

$$
Y_{i j}=\beta_{0}+\beta_{1 j} X_{i j}+e_{i j}
$$

The model used in this study is a multilevel model with a random intercept because it assumes the effect of each independent variable on the response variable is the same for each group. This model is used because it is in accordance with the objectives to be achieved in this study, namely to determine the effect of variations between individuals at level two (district/city) on the status of DPT immunization. Random intercept model is a form of multilevel regression model with the intersection of the y-axis expressed in random form, not fixed as in ordinary linear regression. Different intercepts for each level two unit are used to measure variation between individuals at level two. 
The model formed in this study will not be normally distributed because the response variable is binary categorical. In the multilevel regression model with binary categorical response variables, the model formed will have a binomial distribution from the exponential family. To overcome this abnormal data distribution, a generalized linear model is used. The estimation model for the GLM parameter is the maximum likelihood estimation (MLE). The procedure for calculating MLE in the multilevel regression model was carried out iteratively. The iteration process starts with the estimated parameter values and is updated repeatedly in each iteration process that occurs (Hox, 2010).

The principle of MLE is to maximize the likelihood function by using the inverse of the link function (logit function) to predict the response variable. In general, the binary logistic multilevel model with random intercept model can be written as follows:

$$
\eta_{i j}=\beta_{0 j}+\sum_{p=1}^{P} \beta_{p} x_{p i j}+\varepsilon_{i j}
$$

Then the inverse of the logit function for data with a binomial response variable is defined as follows:

$$
\pi_{i j}=F(\eta)=\frac{e^{\eta}}{\left(1+e^{\eta}\right)}
$$

Where e represents the exponential function, $F(\eta)$ is the logistic transformation of. The new equation with being on the right hand side as another form of GLM is as follows:

where :

$$
\ln \left[\frac{\pi_{i j}}{1-\pi_{i j}}\right]=\eta_{i j}=\gamma_{00}+\sum_{p=1}^{P} \gamma_{p 0} X_{p i j}+\sum_{q=1}^{Q} \gamma_{0 q} Z_{q j}+U_{0 j}+\varepsilon_{i j}
$$

$\gamma_{00}=$ fixed intercept , is the overall average,

$\gamma_{p 0}=$ fixed effect for the $\mathrm{p}$ explanatory variable (fixed slope) with $p=1,2, \ldots, P$,

$X_{p i j}=p$ explanatory variables at first level for individuals $i$ within group $j$ at second level where $p=1,2, \ldots, P$,

$Z_{q j}=$ explanatory variable $q$ at second level for group $j$ where $q=1,2, \ldots, Q$,

$U_{0 j}=$ group random effect $j$ at second level,

$\varepsilon_{i j}=$ residual for individual $i$ at first level within group $j$ at second level

Following are the stages of binary multilevel logistic regression analysis in brief:

1. Testing the random effect using the Likelihood Ratio Test

2. Calculation of the Intraclass Correlation Coefficient (ICC) value

3. Simultaneous testing of parameter significance

4. Testing the significance of the parameters partially

5. Interpreting parameters with odds ratio

\section{RESULT AND DISCUSSION}

\section{Descriptive Analysis}

Based on the 2017 Susenas data processing, the percentage of children aged 12-59 months who did not receive DPT immunization at all was $13.7 \%$. Meanwhile, $86.3 \%$ of other children received complete or incomplete DPT immunization. This figure is still low and has not reached the 2015-2019 strategic plan target which states that the target for complete immunization coverage on a national scale is $93 \%$. This can be caused by many factors, both from the individual characteristics and characteristics that are influenced by the environment in which the 12-59 month old child lives.

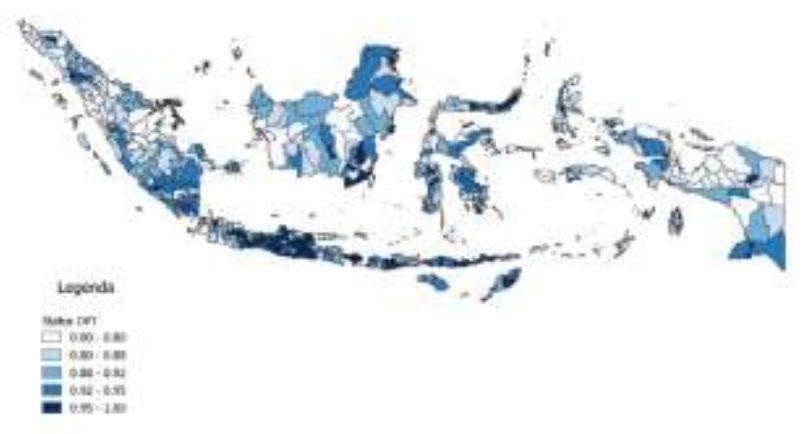

Figure 3. Map of the Distribution of DPT Immunization Status in Children aged 12-59 Months in Indonesia in 2017 
Figure 3 is a map of the distribution of immunization coverage in districts/cities in Indonesia in 2017. As can be seen in Figure 4, the darker the color, the higher the achievement of immunization coverage in the area. Dark colors tend to gather on the islands of Java, Bali, while light colors tend to gather on the islands of Sumatra and eastern Indonesia (Papua and Maluku). The distribution of DPT immunization achievements in regencies/cities on the islands of Sumatra, Kalimantan, Sulawesi tends to be scattered, some have high immunization achievements but some are low.

Table 1. Characteristics of Children Aged 12-59 Months in Indonesia in 2017 Based on Independent Variables

\begin{tabular}{cc}
\hline Variables (Individual Factors) & Percentage (percent) \\
\hline Classification of residence & \\
Rural & 59,1 \\
Urban & 40,9 \\
Mother's Highest Education & \\
S SMP & 58,2 \\
> SMP & 41,8 \\
Possession of an immunization card (KIA or KMS book) & \\
Do not have an immunization card & 12,4 \\
Have an immunization card & 87,6 \\
Mother's working status & 52,3 \\
Does not work & 47,7 \\
Work & \\
Birth Order & \\
Poverty Status & 18,6 \\
Poor & 81,4 \\
Not Poor & \\
\hline
\end{tabular}

Source : Susenas 2017, processed

Based on table 1, it can be seen that the percentage of children aged 12-59 months is higher in rural areas than in urban areas. The difference between the two is $18.2 \%$. Children aged 12-59 months who have mothers with the highest education more than junior high school are $58.2 \%$ while the percentage of children aged 12-59 months who have mothers with the highest education $>$ junior high school is $41.8 \%$. There are about $12.4 \%$ of children aged $12-59$ months who do not have an immunization card, the rest have an immunization card, whether it's a KIA or KMS book. Children aged 12-59 months who have mothers who do not work more than children with mothers who work with a difference of $4.6 \%$. In addition, $18.6 \%$ of children aged 12-59 months came from families with poor household status, the rest came from non-poor households.

In fact, more children aged 12-59 months who did not receive DPT immunization came from rural areas than urban areas, which was $15.7 \%$. As many as $18.8 \%$ of children aged $12-59$ months who did not receive DPT immunization came from mothers with the highest education in junior high school, higher than children aged 12-59 months from mothers with junior high school education and above only $10.7 \%$. Then, $43.4 \%$ of children aged $12-59$ months who did not receive DPT immunization and did not have an immunization card. Meanwhile, children aged 12-59 months who did not receive DPT immunization but had an immunization card were only 7.8\%. Children aged 12-59 months who did not receive DPT immunization for the status of mothers who did not work had the same percentage as children aged 12-59 months who had working mothers. Based on the order of birth, the later the birth order of children aged 12-59 months, the higher the percentage who did not receive DPT immunization. Then, based on their poverty status, the percentage of children aged 12-59 months from poor households is higher than that of children from non-poor households, which is $17.8 \%$. 


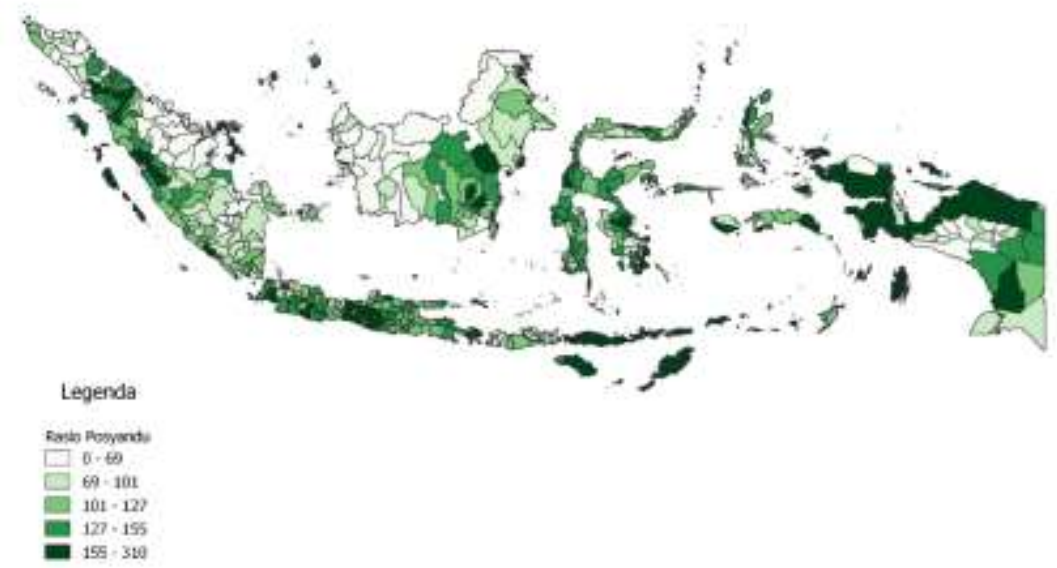

Figure 4. Map of Distribution of Posyandu Ratio in Indonesia in 2017 Source: Provinsi dalam Angka 2018, processed

It is undeniable that the success of achieving immunization targets must be balanced with the availability of health facilities to remote areas. It can be seen in Figure 4 that the availability of posyandu for each district is different. Areas with solid green color indicating that the ratio of posyandu with 100,000 population is quite high are scattered in regencies/cities on the islands of Java, Bali, East Nusa Tenggara, and Papua. As for the white color which indicates the availability of posyandu, which are very less spread out in regencies/cities in Sumatra, Kalimantan, Papua. This indicates that the availability of health facilities providing immunizations is not evenly distributed for all districts/cities in Indonesia.

GRDP describes the level of economic condition of a region, whether carried out by the community, private sector or government in a certain period. A high rate of economic growth in future developments is still needed and must be pursued, with the aim of achieving maximum targets by meeting basic needs. Basic human needs exist in various aspects, basic human needs for health include improving nutrition and health services which are the rights of every citizen protected by the Constitution (Bhakti, 2014). Improving health services is basically an investment in human resources to achieve a prosperous society. The level of public health will greatly affect the level of community welfare (Adjasi and Osei, 2007).

Figure 5 describes the distribution of GRDP in districts/cities in Indonesia. Eastern Indonesia tends to have a lighter color for the value of GRDP, while the dark red color is spread over the western and central parts of Indonesia. This indicates that economic growth is still lacking in the eastern region which can impact on the lack of fulfillment of the basic health needs of the population, such as improving nutrition and health services.

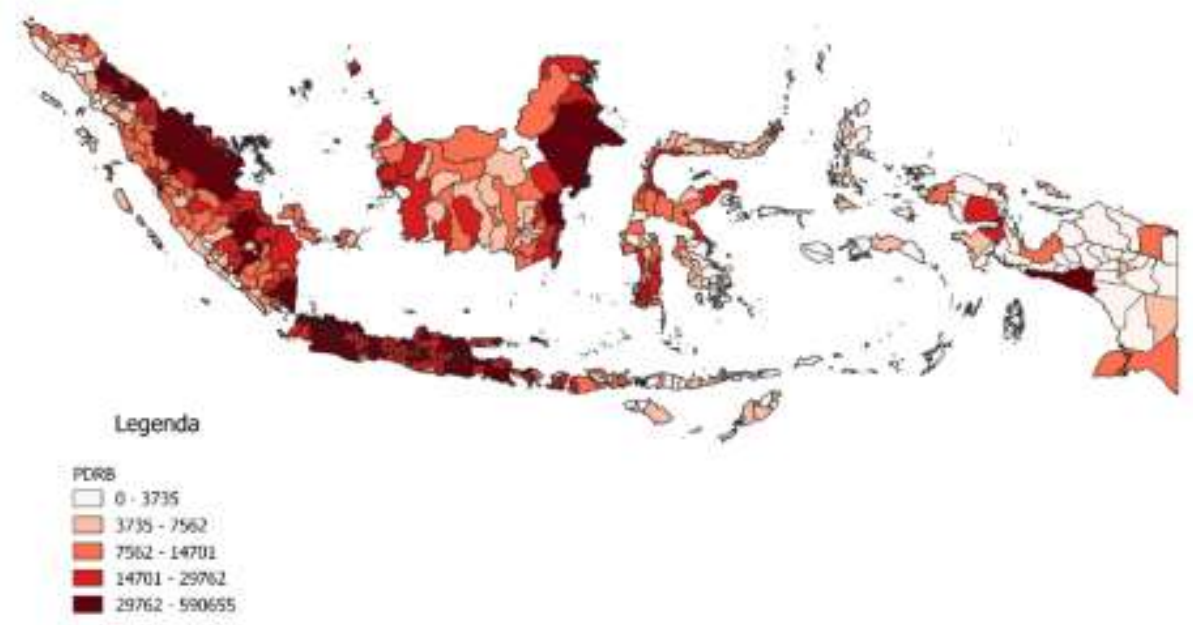

Figure 5. Map of GRDP Distribution in Indonesia in 2017

Source: BPS, processed 


\section{Inferential Analysis}

Based on the results of the processing that has been carried out, it can be seen that the likelihood ratio test value obtained is 3393.84 and the $\mathrm{p}$-value is 0.00 . With an alpha value of 5 percent, the resulting decision is to reject $\mathrm{H}_{0}$ because the LR test $=3393,84>\chi_{(0.05 ; 1)}^{2}=3,84$ and the p-value $<=0.05$. Therefore, it can be concluded that with a significance level of 5 percent there is a significant random effect, which means that the binary multilevel logistic regression model is better used in this study than the ordinary logistic regression model (one level) to analyze the factors that affect the status of the population. DPT immunization in children aged 12-59 months in Indonesia in 2017.

The result of calculating the ICC value in this study is 0.2219 . This figure of 0.1438 illustrates that there is a 22.19 percent diversity of DPT immunization status in children aged 12-59 months in Indonesia in 2017 which is caused by differences in characteristics between districts/cities. Meanwhile, for simultaneous parameter testing, the $G$ test is carried out. The resulting $G$ value will be compared with the value $\chi_{(0,05 ; 9)}^{2}=16,92$. The decision that can be taken is to reject $\mathrm{H} 0$ because the value of $\mathrm{G}=$ $4999,42>\chi_{(0,05 ; 9)}^{2}=16,92$ so that it can be concluded that with a significance level of 5 percent there is at least one independent variable that affects DPT immunization status in children aged 12-59 months in Indonesia in 2017.

Partial parameter significance test was conducted to determine the effect of each explanatory variable, both individual and contextual factors, on DPT immunization status in children aged 12-59 months in Indonesia. The following is a test of each variable, both individual and contextual factors from the multilevel logistic regression model binary with random intercept.

Table 2. Partial Parameter Test Results

\begin{tabular}{|c|c|c|c|c|}
\hline Variables & Coefficient & $\begin{array}{c}\text { Standard } \\
\text { Error }\end{array}$ & $\begin{array}{c}\mathrm{P}- \\
\text { value }\end{array}$ & $\begin{array}{l}\text { Odds } \\
\text { Ratio }\end{array}$ \\
\hline \multicolumn{5}{|c|}{ Individual Factors } \\
\hline \multicolumn{5}{|l|}{ Classification of residence } \\
\hline \multicolumn{5}{|l|}{ Rural (ref) } \\
\hline Urban & 0,1170 & 0,0398 & $0,003 *$ & 1,1241 \\
\hline \multicolumn{5}{|l|}{ Mother's Highest Education } \\
\hline $\begin{array}{l}\leq \mathrm{SMP}(\text { ref }) \\
>\text { SMP }\end{array}$ & 0,0381 & 0,0323 & 0,236 & 1,0389 \\
\hline \multicolumn{5}{|c|}{ Possession of an immunization card (KIA or KMS book) } \\
\hline $\begin{array}{l}\text { Do not have an immunization card (ref) } \\
\text { Have an immunization card }\end{array}$ & 0,3286 & 0,0113 & $0,000^{*}$ & 1,3890 \\
\hline \multicolumn{5}{|l|}{ Mother's working status } \\
\hline \multicolumn{4}{|l|}{ Work } & 10,5687 \\
\hline Birth Order & $-0,0490$ & 0,0113 & $0,000^{*}$ & 0,9522 \\
\hline \multicolumn{5}{|l|}{ Poverty Status } \\
\hline $\begin{array}{l}\text { Poor (ref) } \\
\text { Not Poor }\end{array}$ & 0,2389 & 0,0421 & $0,000 *$ & 1,2698 \\
\hline \multicolumn{5}{|c|}{ Contextual Factors } \\
\hline InGRDP & 0,0422 & 0,0151 & $0,005^{*}$ & 1,0431 \\
\hline Posyandu Ratio to 100.000 Population & 0,0039 & 0,0039 & $0,000 *$ & 1,0039 \\
\hline
\end{tabular}

Based on the partial test above, the following model is formed:

$\ln \left[\frac{\widehat{\mu_{l \jmath}}}{1-\widehat{\mu_{l j}}}\right]=-0,8662+0,0422 \ln \operatorname{lRDP}_{\mathrm{j}}{ }^{*}+0,0039$ posyanduratio $_{\mathrm{j}}{ }^{*}+0,1170$ classification_residence ${ }_{\mathrm{ij}}{ }^{*}$ $+0,0381$ workmom $+0,3286$ edu_mom ${ }_{i j} *+2,3579$ immunizationcard ${ }_{i j} *-0,0490$ birth_order $*+$ 0,2389 poverty_stat ${ }_{i j} *$

Variables from these individual factors include residence classification, mother's highest education, ownership of an immunization card, birth order, and poverty status. While the variables of contextual factors that significantly affect the DPT immunization status in children aged 12-59 months in Indonesia include the ratio of puskesmas to 100,000 population and lngrdp. 
Mother's working status has no significant effect on DPT immunization status in children aged 12-59 months in Indonesia, it can be seen from table 2 that the p-value generated by this variable is $>=$ 0.05. This is in line with the research conducted by Triana (2016) which concluded that the working status of the mother does not affect the provision of immunization. In his research, it is stated that mothers who do not work do have more free time than mothers who work, but this is not an excuse for working mothers not to take their children to health services.

Children aged 12-59 months who live in urban areas have a tendency to be given DPT immunization by 1.1241 times compared to children aged 12-59 months who live in rural areas. This result is in line with research conducted by Nainggolan et al (2016) which states that in rural areas there is a tendency to lack immunization because health services are too centralized in urban areas and health services are rarely found in rural areas, so this affects the provision of immunization.

The tendency of children aged 12-59 months who came from mothers with the highest education at least junior high school had a tendency to get DPT immunization by 1.3890 times greater than children aged 12-59 months who came from mothers with the highest education of junior high school. This is in line with the research conducted by Phukan et al (2008) which said that the main reason for the low immunization coverage was the low education of a mother. Low maternal education causes a mother to lack information and knowledge, especially regarding basic immunization for children.

The tendency of children aged 12-59 months who have an immunization card to get DPT immunization is 10.5687 times greater than children aged 12-59 months who do not have an immunization card. The Ministry of Health (2010) stated that the main causes of low immunization coverage were because the immunization service locations were far and difficult to reach, the service schedule was irregular and not in accordance with community activities, the unavailability of immunization cards (KIA and KMS books), low public awareness and knowledge about benefits, and timing of immunization. In line with research conducted by Chhabra et al. (2007), it is stated that one of the variables that significantly affects the completeness of immunization coverage is ownership of an immunization card.

The more children's birth order, the tendency of the child to get DPT immunization is 0.9522 , which is smaller than the child whose birth order is early. This is in line with the research conducted by Barreto and Rodriguez (1992) which concluded that mothers with many children had lower immunization coverage than mothers with few children. In his research it is said that mothers with many children tend to have difficulty in immunizing their children. It is possible that there are other factors that contribute to the low immunization coverage of children who are born later. Lack of time and resources with the larger family can lead to a lack of attention to the child.

The tendency of children aged 12-59 months from non-poor families to receive DPT immunization is 1.2698 times greater than children aged 12-59 months from families with low economic status. This is supported by research conducted by Lakew et al (2015) which concluded that children from poor families tend to have lower immunization coverage than children from rich families. Similarly, the conclusions obtained in the study of Topuzoglu et al (2005) which said that children from rich families had a higher chance of getting immunizations. Because usually mothers who come from rich families have better education and knowledge, especially regarding children's health than mothers who come from families with low economic status.

The coefficient value obtained in the posyandu ratio variable to 100,000 residents is 0.0039 so that the odds ratio obtained by this variable is 1.0039 . So it can be concluded that for every additional 1 posyandu in a district/city, the tendency of children aged 12-59 months to receive immunization is 1.0039 times assuming the other variables are constant. This is supported by research conducted by Topuzoglu et al (2005) which states that the availability of health facilities has a significant effect on immunization coverage in Istanbul, Turkey. In his research it is said that basically the immunization program that has been launched by the government will not run if in an area there are no facilities that provide immunization. As stated by Notoadmodjo (2007) that health facilities and ease of transportation facilitate the formation of a behavior in the community. Examples of behavior that can occur are the behavior of parents to immunize their children, so in that environment there must be doctors, midwives, posyandu, health centers, etc.

The value of the odds ratio on the $\operatorname{lnPDRB}$ variable is 1.0431 , which means that for every one percent increase in GRDP, the tendency of children aged 12-59 months to receive immunization is 1.0431 times assuming other variables are constant. The value of GRDP describes the level of economic condition of a region, whether carried out by the community, private sector or government in a certain period. A high rate of economic growth in future developments is still needed and must be pursued, with 
the aim of achieving maximum targets by meeting basic needs. Basic human needs exist in various aspects, basic human needs for health include improving nutrition and health services which are the rights of every citizen protected by the Constitution (Bhakti, 2014). Improving health services is basically an investment in human resources to achieve a prosperous society. The level of public health will greatly affect the level of community welfare (Adjasi and Osei, 2007).

\section{CONCLUSIONS}

Based on the results of the research that has been done, the following conclusions can be drawn:

1. As many as $13.7 \%$ of children aged 12-59 months in Indonesia who have never received DPT immunization at all. Characteristics of children aged 12-59 months who did not receive DPT immunization, the majority lived in rural areas, did not have an immunization card, came from poor families, had mothers with the highest education in junior high school, and were born recently to mothers with many children.

2. Individual variables that have a significant effect on the provision of DPT immunization to children aged 12-59 months in Indonesia in 2017 include the classification of residence, ownership of the birth order immunization card, the mother's highest education, and household poverty status. While the contextual variables that have a significant effect on the provision of DPT immunization to children aged 12-59 months are the ratio of posyandu per 100,000 population and GRDP.

3. The diversity of the status of giving DPT immunization to children aged 12-59 months in Indonesia in 2017 caused by differences in characteristics between districts/cities by 22.19 percent.

For the government, it is hoped that it will be more focused on increasing knowledge of the importance of immunization for parents, especially mothers by increasing the level of education or providing socialization, then by improving the quality of health facilities or facilitating access to health facilities in Eastern Indonesia. DPT immunization coverage is still relatively low. For further research, it can be combined with qualitative research to examine the causes of children aged 12-59 months not receiving DPT immunization at all. Moreover, added to the issue that immunizations and vaccines are not halal. It is necessary to further investigate the effect of media exposure on mothers who have toddlers. Then it is necessary to add a variable of travel time or the level of field convenience to health facilities so that more accurate and comprehensive conclusions can be obtained, not only from the availability of health facilities.

\section{REFERENCES}

Bappenas. (2015). Rencana Pembangunan Jangka Menengah Nasional Tahun 2015-2019. Bappenas Goldstein, H. (1995). Multilevel Statistical Models. London, Edward Arnold. New York, Halsted Press Hosmer, D.W. dan S. Lemeshow, (2000). Applied Logistic Regression. Second Edition, John Willey \& Sons, New York.

Hox, J.J., 2010. Multilevel Analysis Techniques and Applications. 2nd ed. New York, USA: Routledge. Irawati, Dian. (2011). Faktor Karakteristik Ibu yang Berhubungan dengan Ketepatan Imunisasi DPT Combo dan Campak di Pasuruan. Hospital Majapahit, 3(1).

Kemenkes RI. (2015). Rencana Strategis Kementerian Kesehatan Tahun 2015-2019. Kemenkes RI

Kemenkes RI. (2013). Imunisasi Murah dan Efektif Imunisasi Melindungi Anak Indonesia dari Wabah, Kematian atau Kecacatan. Kemenkes RI. Retrieved from https://sehatnegeriku.kemkes.go.id/baca/rilis-media/20130418/477668/imunisasi-murah-danefektif-imunisasi-melindungi-anak-indonesia-dari-wabah-kematian-atau-kecacatan/

Kemenkes RI. (2015). Profil Kesehatan Indonesia 2015. Kemenkes RI

Kemenkes RI. (2016). Profil Kesehatan Indonesia 2016. Kemenkes RI

Kemenkes RI. (2017). Profil Kesehatan Indonesia 2017. Kemenkes RI

Kemenkes RI. (2018). Pemerintah Optimis KLB Difteri Bisa Teratasi. Kemenkes RI. Retrieved from https://www.kemkes.go.id/article/view/18011500004/pemerintah-optimis-klb-difteri-bisateratasi.html

Kemenkes RI. (2017). Imunisasi Efektif Cegah Difteri. Kemenkes RI. Retrieved from http://p2p.kemkes.go.id/imunisasi-efektif-cegah-difteri/ 
Lakew, Yihunie dkk. (2015). Factor Influencing Full Immunization Coverage among 12-23 Months of Age Children in Ethiopia Evidence from the National Demographic and Health Survey in 2011. BMC Public Health, 15:728.

Mubarak. (2007). Promosi Kesehatan. Graha Ilmu. Yogyakarta.

Nainggolan, Olwin dkk. (2016). Pengaruh Akses ke Fasilitas Kesehatan terhadap Kelengkapan Imunisasi Baduta (Analisis Riskesdas 2013). Media Libangkes, 26(1),15-28.

Notoatmodjo, Soekidjo. (2010). Ilmu Perilaku Kesehatan. Jakarta: Rineka Cipta

Phukan, Rup Kumar dkk (2008). Factors Associated with Immunization Coverage of Children In Assam, India: Over the First Year of Life. Oxford University Press

Rahmawati, Sri Pinti. (2007). Analisis Faktor Sumber Daya Manusia yang Berhubungan dengan Hasil Kegiatan Imunisasi Dasar Bayi oleh Petugas Imunisasi Puskesmas di Kabupaten Blora Tahun 2006 [Tesis]. Semarang: Universitas Diponegoro.

Topuzoglu, A dkk. (2005). Assesment of Sociodemographic Factors and Socio-Economic Status Affecting the Coverage of Compulsory and Private Immunization Services in Istanbul, Turkey. Public Health, 119, 862-869. 